\title{
Modelling predicts that soybean is poised to dominate crop production across Africa
}

\author{
Christine H. Foyer ${ }^{1,2}$ (D) | Kadambot H.M. Siddique ${ }^{3}$ | Amos P.K. Tai ${ }^{4,5}$ | Sven Anders ${ }^{6}$ | \\ Nándor Fodor $^{1,7}$ | Fuk-Ling Wong ${ }^{5,8}$ | Ndiko Ludidi ${ }^{9}$ | Mark A. Chapman ${ }^{10}$ | \\ Brett J. Ferguson ${ }^{11} \mid$ Michael J. Considine ${ }^{1,2,3,12}$ (D) | Florian Zabel ${ }^{13} \mid$ P.V. Vara Prasad ${ }^{14}$ (D) | \\ Rajeev K. Varshney ${ }^{15}$ (D) । Henry T. Nguyen ${ }^{16}$ (D) । Hon-Ming Lam ${ }^{5,8}$ (D)
}

${ }^{1}$ Centre for Plant Sciences, Faculty of Biological Sciences, University of Leeds, Leeds, UK

${ }^{2}$ School of Molecular Science, The University of Western Australia, Perth, Western Australia, Australia

${ }^{3}$ The UWA Institute of Agriculture and School of Agriculture and Environment, The University of Western Australia, Perth, Western Australia, Australia

${ }^{4}$ Earth System Science Programme, The Chinese University of Hong Kong, Shatin, Hong Kong

${ }^{5}$ Center for Soybean Research of the State Key Laboratory of Agrobiotechnology, The Chinese University of Hong Kong, Shatin, Hong Kong

${ }^{6}$ Department of Resource Economics and Environmental Sociology, University of Alberta, Edmonton, Alberta, Canada

${ }^{7}$ Centre for Agricultural Research, Hungarian Academy of Sciences, Agricultural Institute, Martonvásár, Hungary

${ }^{8}$ School of Life Sciences, The Chinese University of Hong Kong, Shatin, Hong Kong

${ }^{9}$ Department of Biotechnology and the DST/NRF Centre of Excellence in Food Security, University of the Western Cape, Bellville, South Africa

${ }^{10}$ Biological Sciences, University of Southampton, Southampton, UK

${ }^{11}$ Centre for Integrative Legume Research, School of Agriculture and Food Sciences, The University of Queensland, Brisbane, Queensland, Australia

${ }^{12}$ The Department of Primary Industries and Regional Development, South Perth, Western Australia, Australia

${ }^{13}$ Ludwig-Maximilians-Universität München, Munich, Germany

${ }^{14}$ Department of Agronomy, College of Agriculture, Kansas State University, Manhattan, Kansas, USA

${ }^{15}$ Center of Excellence in Genomics and Systems Biology, International Crops Research Institute for the Semi-Arid Tropics (ICRISAT), Patancheru, Hyderabad, Telangana, India

${ }^{16}$ Division of Plant Sciences and National Center for Soybean Biotechnology, University of Missouri, Columbia, Missouri

\section{Correspondence}

Christine H. Foyer, Centre for Plant Sciences, Faculty of Biological Sciences, University of Leeds, Leeds LS2 9JT, UK.

Email: c.foyer@leeds.ac.uk

Funding information

Worldwide University Network (WUN); BBSRC, Grant/Award Number: BB/N004914/1; ARC, Grant/Award Numbers: DP150103211 and DP130102266; Hermon Slade Foundation, Grant/Award Number: DP130103084; ViceChancellor Discretionary Fund, Grant/Award Number: VCF2015006; General Research Fund, Grant/Award Number: 14323116

\begin{abstract}
The superior agronomic and human nutritional properties of grain legumes (pulses) make them an ideal foundation for future sustainable agriculture. Legume-based farming is particularly important in Africa, where small-scale agricultural systems dominate the food production landscape. Legumes provide an inexpensive source of protein and nutrients to African households as well as natural fertilization for the soil. Although the consumption of traditionally grown legumes has started to decline, the production of soybeans (Glycine max Merr.) is spreading fast, especially across southern Africa. Predictions of future land-use allocation and production show that the soybean is poised to dominate future production across Africa. Land use models project an expansion of harvest area, whereas crop models project possible yield increases. Moreover, a seed change in farming strategy is underway. This is being driven largely by the combined cash crop value of products such as oils and the high nutritional benefits of soybean as an animal feed. Intensification of soybean production has the potential to reduce the dependence of Africa on soybean imports. However, a successful "soybean bonanza" across Africa
\end{abstract}


necessitates an intensive research, development, extension, and policy agenda to ensure that soybean genetic improvements and production technology meet future demands for sustainable production.

\section{1 | INTRODUCTION}

Assuring sustainable food security for millions of poor producers and consumers across Africa living on $\$ 2$ a day or less remains a serious problem, exacerbated by malnutrition (Figure 1). Adding to the pressure exerted by the rural poor are the emerging demands of urban African middle-class consumers, who strive for diets of higher nutritional quality and richer in animal proteins. Although these food choices may be influenced by factors such as relative prices, advertising, and perception, they are primarily driven by personal preferences in Africa, as in other countries where increased wealth has been accompanied by an increased consumption of meats and dairy products. Satisfying the demands of a rapidly growing population with an increasing appetite for protein rests on the agricultural sector. Smallholder farmers are the bedrock group, who manage $80 \%$ of farmland and produce $70 \%$ of food in Africa (FAO, 2012). Plagued by resource-constrained farming conditions and inadequate technologies, African producers continue to struggle with poor economic returns and trade-offs between subsistence and cash crop production (Timmer, 1997, 2004). Much needed improvements in productivity and choice of crops and farm animals are limited by the availability and access to agricultural inputs and resources. Better training, access to finance, and most critically, quality production factors (including seed quality and other inputs) are necessary to eliminate the causes of the much debated "yield gap," that is, the difference between maximum achievable crop yields and actual yields (Anderson, Johansen, \& Siddique, 2016), witnessed by producers across much of Africa (Mauser et al., 2015). Many African countries have very low agricultural productivity and large yield gaps, which can be attributed in part to environmental constraints including poor soil quality and insufficient water availability. In addition, a lack of technology, inappropriate institutions and/or poor governance, land tenure, declining infrastructure, and underdeveloped marketing or poor market infrastructure make producers adopt risk-minimizing cropping choices. It is no surprise therefore that the African yield gap and agricultural poverty cycles continue to persist (Maxwell, 1996).

The pivotal role of grain legumes in assuring the current and future sustainability of agriculture across Africa is well documented (Foyer et al., 2016; Sinclair, Marrou, Soltani, Vadez, \& Chandolu, 2014). The symbiotic nitrogen fixation properties of legumes mean that they are suitable for cultivation on a wide variety of soils (Ferguson et al., 2010). Soil fertility management through either crop rotation or intercropping has long been an essential resource for poor farmers unable to access and/or afford more expensive inorganic fertilizer inputs. Further, symbiotic nitrogen fixation also helps protect other vital nutrients such as phosphate (Foyer et al., 2016). Grain legumes are ideally suited to the task of mitigating many of the agronomic and economic constraints faced by producers, while providing positive impacts on soil health (Ferguson et al., 2010; Gresshoff et al., 2015;
Jensen et al., 2012). A large number of grain legume species are grown across Africa including many underutilized, orphan, or neglected crops. Unfortunately, orphan crops are widely considered to be the "poor man's protein," particularly by the growing numbers of middle-class consumers across Africa (i.e., Nigeria, South Africa, and Uganda), who prefer diets that are rich in animal protein (Chivenge, Mabhaudhi, Modi, \& Mafongoya, 2015). However, these largely undervalued and unappreciated locally adapted crops have essential stress tolerance traits with high yield stability under suboptimal and often difficult climatic conditions (Cullis \& Kunert, 2017). Despite these clear benefits, these underutilized and mainstream grain legume species are not viewed as the next generation of "super crops," but rather they face stagnation and declining consumption across the continent and much of the developing world. In contrast, increased demands for soybean production are being driven by increasing incomes and urbanization and a global dietary transition to diets that are higher in refined sugars, refined fats/oils, and meats (Tilman \& Clark, 2014). It is not surprising that research by the European Commission (Melo et al., 2015) confirmed that there is a general decline in consumption within these food groups, which have negative income elasticities, with each additional $\$ 1$ in available income. In contrast, the income elasticities for meat, fish, eggs, and dairy (sources of protein perceived as more luxurious in the eyes of many Africa consumers) are among the highest positive elasticities reported by this research (Melo et al., 2015). Current evidence (Table S1) suggests that many grain legumes are destined to face a future as protein of last resort for the rural poor. It is becoming increasingly likely that meat protein consumption will expand across Africa, as grain legume protein and the energy from maize become used more extensively to produce the animal protein. This raises the question of which of the many protein-rich grain legumes grown across Africa is likely to meet demand. We consider that the answer, based on current data and Food and Agricultural Organization (FAO) predictions, is soybeans, which are discussed in detail below. Moreover, most of the countries in Africa south of the Sahara Desert extending all the way to South Africa are suitable for soybean production. Given these facts, we discuss how the rapidly growing popularity of soybean production across Africa could mark the start of a soybean revolution.

\section{2 | THE GROWING SUCCESS OF SOYBEAN}

Fifty years ago, soybean was an underutilized niche crop that lacked processing and consumer markets. Global production of soybean has increased 13-fold since 1961 to over 340 million metric tonnes (MMT) in 2016 (FAOSTAT, 2017). Today, soybean is one of the five most important crops worldwide. The global import and export values of soybean have outstripped all of the other major crops such as wheat, rice, and maize, even without the inclusion of soybean oil or other processed forms. Africa has the land, climate, and motivation 
Wasting prevalence in children under age of $\mathbf{5}$ in Sub-Saharan Africa
Stunting prevalence in children under age of $\mathbf{5}$ in Sub-Saharan Africa
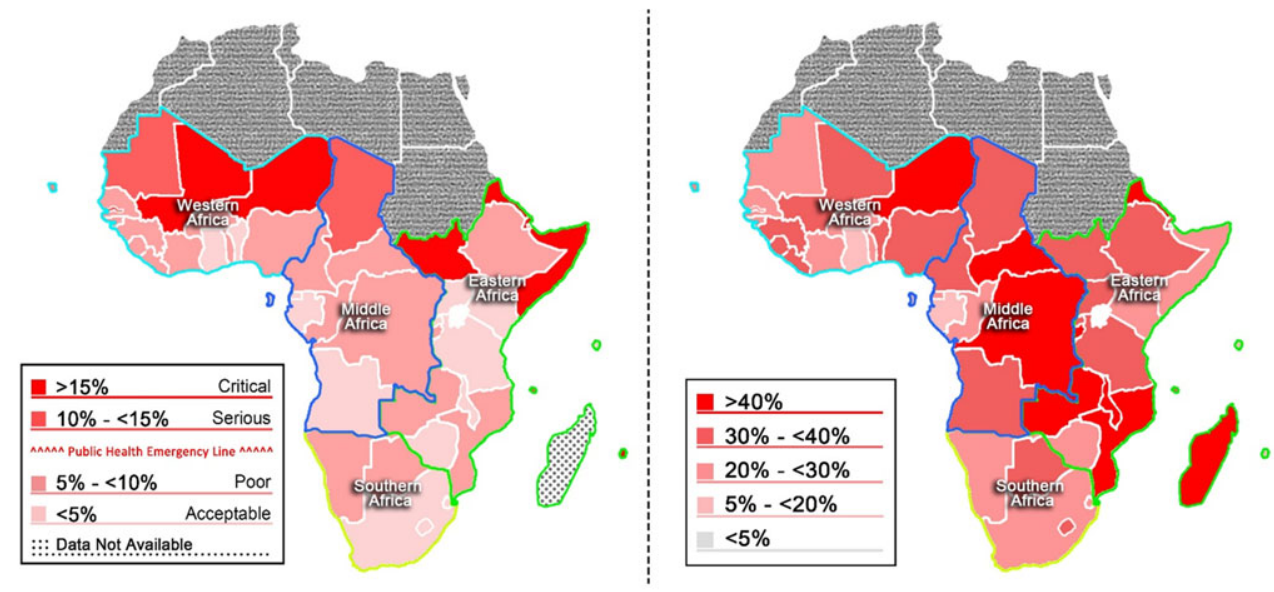

\begin{tabular}{|c|c|c|c|c|}
\hline & Eastern Africa & Southern Africa & Western Africa & Middle Africa \\
\hline $\begin{array}{l}\text { Average wasting prevalence in children under } \\
\text { age of } 5(\%)\end{array}$ & 9.18 & 4.76 & 8.95 & 6.37 \\
\hline $\begin{array}{l}\text { Average stunting prevalence in children under } \\
\text { age of } 5(\%)\end{array}$ & 34.69 & 27.42 & 29.71 & 30.51 \\
\hline Population under 5 ('000s) & 61,878 & 6,369 & 58,272 & 26,156 \\
\hline Survey Years & $1995-2016$ & 1994-2014 & $2006-2016$ & $2010-2016$ \\
\hline
\end{tabular}

* Wasting prevalence, stunting prevalence and population data were not available in Ethioppia PDR, Mayotte, Réunion and Saint Helena Ascension and Tristan da Cunha. Wasting prevalence data was not available in Madagascar.

FIGURE 1 Wasting and stunting prevalence in children under age 5 in Sub-Saharan regions (UNICEF/WHO/World Bank Group, 2017). The data were obtained from the FAO database (FAOSTAT). The definition of different regions is according to FAO; Eastern Africa: Burundi, Comoros, Djibouti, Eritrea, Ethiopia, (Ethiopia PDR), Kenya, (Madagascar), Malawi, Mauritius, (Mayotte), Mozambique, (Réunion), Rwanda, Seychelles, Somalia, South Sudan, Uganda, United Republic of Tanzania, Zambia, Zimbabwe; Middle Africa: Angola, Cameroon, Central African Republic, Chad, Congo, Democratic Republic of the Congo, Equatorial Guinea, Gabon, Sao Tome and Principe; Southern Africa: Botswana, Lesotho, Namibia, South Africa, Swaziland; Western Africa: Benin, Burkina Faso, Cabo Verde, Côte d'Ivoire, Gambia, Ghana, Guinea, Guinea-Bissau, Liberia, Mali, Mauritania, Niger, Nigeria, (Saint Helena Ascension and Tristan da Cunha), Senegal, Sierra Leone, Togo. Countries with missing or incomplete data were bracketed. Details are shown in Table S1 [Colour figure can be viewed at wileyonlinelibrary.com]

to be a major player in global soybean production in the future. Land dedicated to soybean cultivation in Africa in 2016 exceeded 1.5 million hectares. Development of new rust-resistant varieties and high-yielding lines that are adapted to production in African climates now face a sellers' market, particularly for soybean oil for cooking and high-protein meal cake, which is a much sought-after ingredient in poultry and other animal feeds (Ncube, Roberts, \& Zengeni, 2016). Moreover, in rotation with cereals such as maize and sorghum, soybean production has the potential to provide the bedrock of food and feed supply across Africa. The strong and growing demand for maize and soybeans should provide diverse economic opportunities for smallholders, who are eager to diversify their crop and animal production systems. Hence, we predict sweeping changes in soybean production and use across Africa in the coming decades. We also warn that the current lack of attention to the potential "soybean bonanza" may result in too little research attention being focused on the genetic improvement of soybean and associated production technologies to support increasing production in Africa, especially in a changing climate.

\section{I LEGUME PRODUCTION IN AFRICA}

Traditional grain legume cultivation (Table 1 ) is predominant across Africa (Figure 2); however, substantial variations in production and yield outcomes exist, which reflect productivity ceilings due to soil fertility and moisture (Bill \& Melinda Gates Foundation, 2012; Ortega, Waldman, Richardson, Clay, \& Snapp, 2016; Tadele, 2017). Chickpeas, groundnuts, and soybeans have yields above 1.0 MT ha ${ }^{-1}$, in comparison to common beans and cowpeas that often have yields below 
TABLE 1 Traditionally grown legumes in Africa

Common bean (dry bean: Phaseolus vulgaris L.)

- Provides dietary protein for $>200$ million people in Africa (Buruchara et al., 2011).

- It is the most widely produced grain legume in Sub-Saharan Africa (6 million metric tonnes [MMT], 2014; Table S2).

- Production is steadily transforming from a traditional subsistence to market-oriented grain legume crop, with major impacts on household incomes, food and nutritional security, and national economies.

- The Pan-Africa Bean Research Alliance (PABRA), which is a consortium of 30 bean-producing countries in Africa involving more than 350 partner public and private organizations that are coordinated by the International Centre for Tropical Agriculture, has accelerated the transition of bean from a subsistence crop to a modern commodity in Africa (Buruchara et al., 2011; Pan-Africa Bean Research Alliance, 2017).

- The PABRA model led to the release of more than 200 bean varieties from 2003 to 2010 (Buruchara et al., 2011).

Pigeon pea (Cajanus cajan L.)

- Mainly produced in Kenya, Malawi, Mozambique, Tanzania, and Uganda (Table S2), the current area and production is 1.14 million ha and 1.47 MMT, respectively.

- Since 2001 , area and production have increased by $96 \%$ and $175 \%$, respectively, contributing to $21 \%$ of global production (FAOSTAT).

- About 6 million smallholder subsistence farmers in Eastern and Southern African (ESA) countries cultivate pigeon pea, exporting 0.29 MMT of grain/ year, worth US\$ 203 million (FAOSTAT).

- ESA is a secondary centre of genetic diversity with about 1,500 unique germplasm accessions.

- To date, 34 improved varieties of pigeon pea were released for cultivation in ESA due to an active collaboration between ICRISAT and ESA countries. Cowpea (Vigna unguiculata (L.) Walp.)

- Widely produced across Africa, contributing approximately $94 \%$ of global production (2014; FAOSTAT).

- About 70\% cowpea production is concentrated in Nigeria and Niger (FAOSTAT).

- Cowpea production in Africa more than doubled between 1993 and 2014 to 5.2 MMT.

$900 \mathrm{~kg} \mathrm{ha}^{-1}$ (Figure 2). Together, with other African legumes (Table 1), soybeans are a productivity-enhancing crop (Kerr, Snapp, Chirwa, Shumba, \& Msachi, 2007) and potentially an economically beneficial choice, especially for small- and medium-scale producers (Gresshoff et al., 2015; Kerr et al., 2007). Unfortunately, empirical evidence in support of predictions of future grain legume production overall, and for soybeans in particular, is fragmented. Many such predictions have relied on spatially or temporally uncertain results of crop yield model aggregations, which are considered to be significant when underlying production system factors are often uncertain (Mueller et al. 2012; Porwollik et al., 2017). Despite a paucity of extensive data, the predictions presented here (Figure 3 ) provide the most realistic scenarios and outcomes. In light of overall limitations in available data across Africa, we chose the consistency of the latest available FAO data, confirmed by our own analysis of available data, over aggregations of alternative data sources. We reiterate the concerns in previous studies (Tilman, Balzer, Hill, \& Befort, 2011) regarding the need to overcome major data barriers to predictions of how regional African crop systems might perform under various production conditions, market dynamics, and climate change. Regardless, data from all available sources point to the significant potential of available improved soybean cultivars in sustainable intensification in the coming decades (Tilman et al., 2011).

There is a steady increase in soybean production area in Brazil, and soybean production is gradually moving west and north (from North America) into Canada as well as northwards from Northeast China into Russia, as varieties that are suitable for these more exacting climates become available. There is also a bright future for soybean production in Africa. Soybean is poised to fill Africa's widening gap in the demand for protein, oil, and animal feed legumes that have already uniquely elevated the profile of soybean across southern Africa. However, Africa continues to rely on the investment of largely resource-poor small holders for the majority of crop production. Such producers are inherently limited in their overall ability to adopt the latest soybean technologies and overcome barriers stemming from market access and investment needs (Ray, Mueller, West, \& Foley, 2013; Wilson, 2015). Moreover, limited and inconsistent regional producer price data make accurate predictions of the profitability of soybean rotations problematic, that is, beyond their proven value as substitutes for expensive imports of feedstuffs (Ncube et al., 2016). However, it is important to note that soybeans have the lowest producer price in developing countries (Akibode \& Maredia, 2012). For example, the producer price for soybean in West Africa is significantly lower than the average global producer price for pulse crops (Table S2; Akibode \& Maredia, 2012).

The terms of trade in Africa, soybeans are the most favourable of all the major crops, with export values more than double that of imports (US\$ 57 M cf. US\$ 25 M, 2013; FAOSTAT, 2017). This contrasts starkly with wheat and rice, with trade deficits of US\$ 5.4 and US\$ 7 billion, respectively. Although export is constrained by high transport costs and international subsidies, domestic soybean production offers significant value through regional trade and by reducing dependence on imports (Keyser, 2007). South Africa and Nigeria currently dominate soybean production in Africa, comprising $70 \%$ of the total in 2014 (Akibode \& Maredia, 2012). Demand for soybean cake for animal feed is increasing rapidly, as a consequence of growth in middle-class population in South Africa (Bureau for Food and Agricultural Policy, 2017). In South Africa alone, current production is only $30 \%$ of crushing capacity to about approximately $2 \mathrm{MMT}$, with total demand at 3.5 MMT. Recent rapid growth in Malawi and Zambia illustrates the geographic expansion and diversification of farming systems since the turn of the century (2003-2014; Akibode \& Maredia, 2012). The implementation of soybean-maize crop rotations, supervised by 

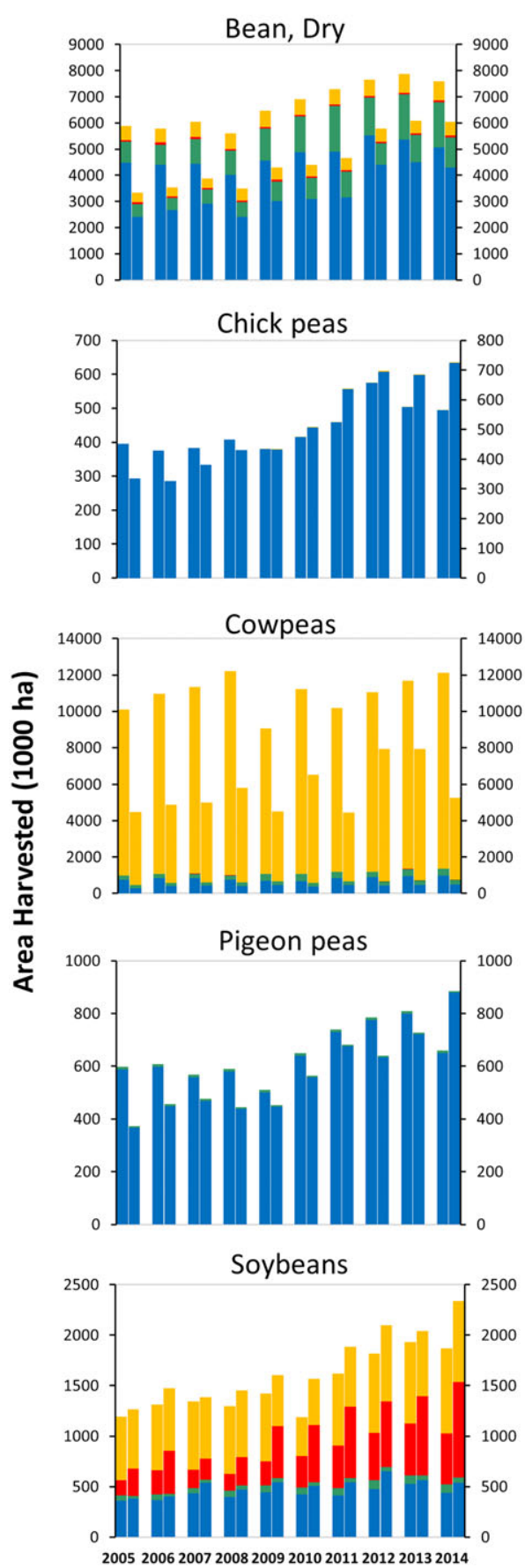
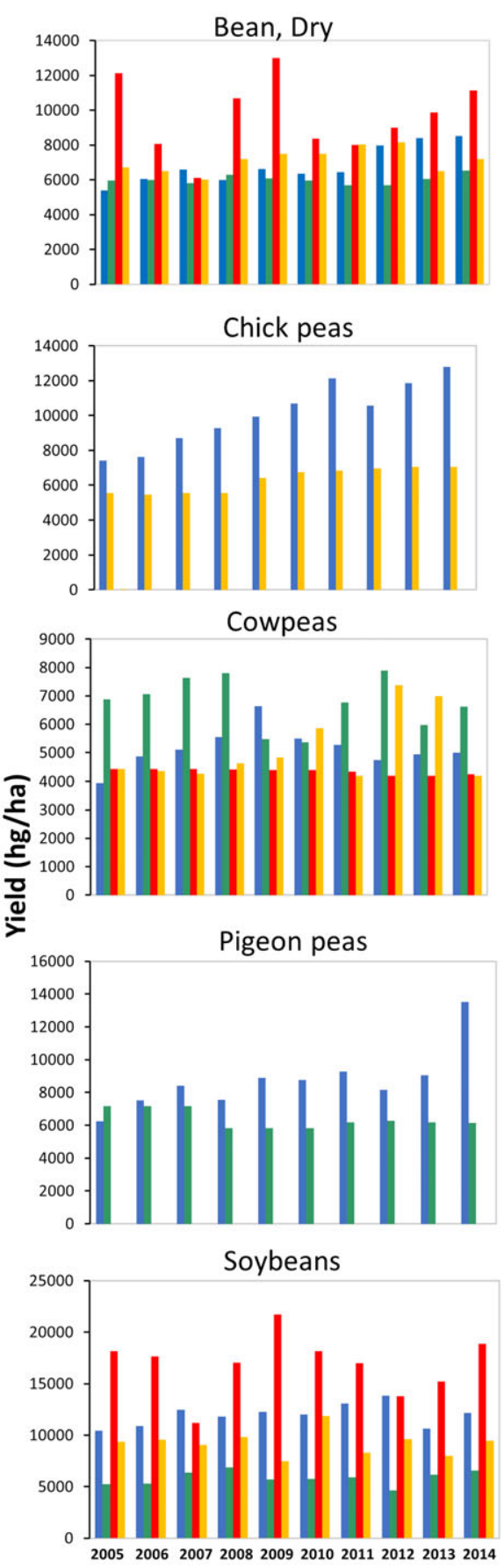

FIGURE 2 Area harvested, production, and yield of five major legumes in Sub-Saharan regions. The area harvested and production (2005-2014) of dry bean, chickpea, cowpea, pigeon pea, and soybean are shown for Sub-Saharan regions, using FAO data (FAOSTAT). The definition of different regions is according to FAO (see legends in Figure 1). Details are shown in Table S2 [Colour figure can be viewed at wileyonlinelibrary. com]

multinational projects such as Support to Agricultural Research for Development of Strategic Crops in Africa has improved on-farm productivity and sustainability. Although opportunities still have to be realized in other African countries such as Tanzania (Wilson, 2015), activities such as the Tanzania Soybean Development Strategy will lead to exponential increases in soybean production, from approximately 6,000 tonnes in 2014 to 2 MMT by 2020 (Akibode \& Maredia, 2012; FAOSTAT, 2017).

\section{4 | MODELS AS TOOLS FOR PREDICTING CLIMATE CHANGE IMPACTS ON AGRICULTURE}

Crop models are used for an increasingly broad range of applications including climate change impact studies (Challinor et al., 2018; Jones et al., 2017). At present, a range of system models with differing degrees of model complexity have become available. These vary in 


\section{FAO soybean data (2000) and projections (2050) for Sub-Saharan Africa}

(a) 2000 data
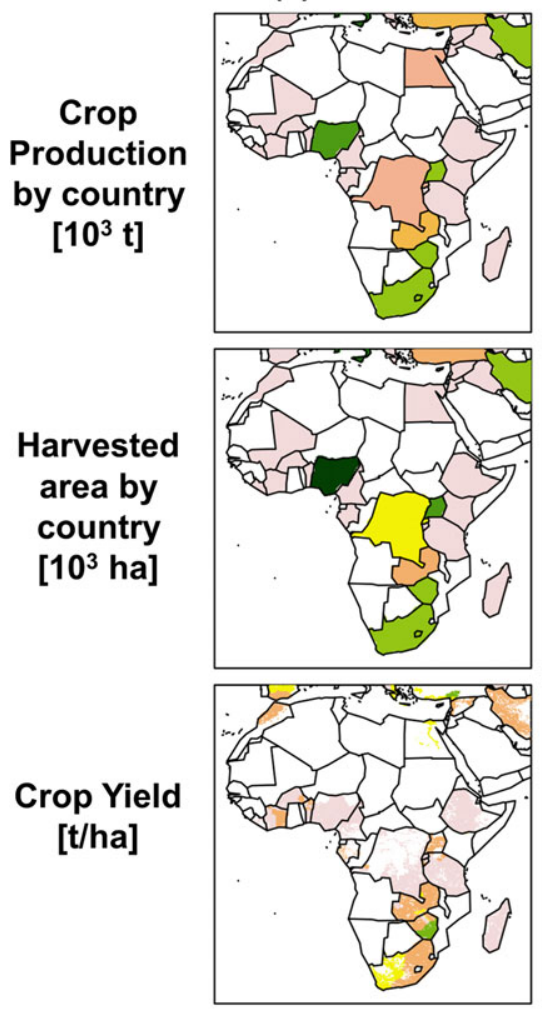

(b) 2050 projections
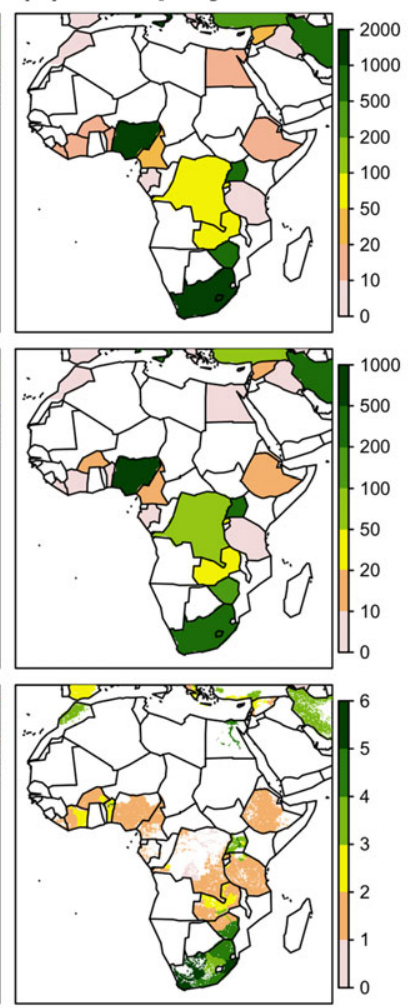

(c) Growth factor
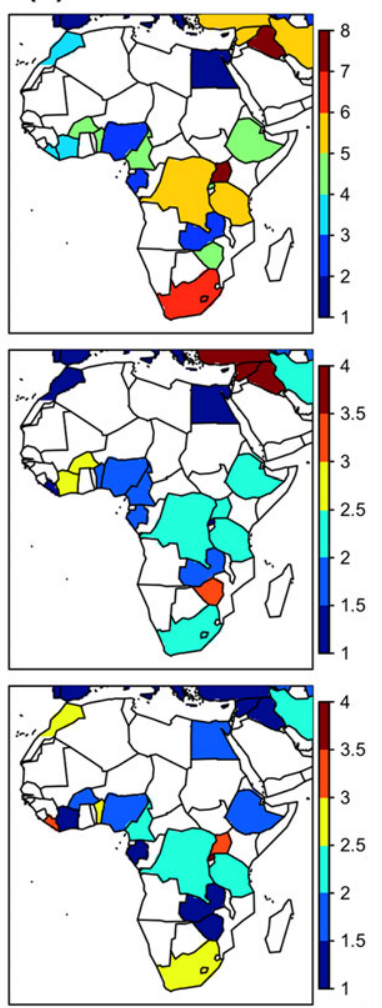

FIGURE 3 FAO soybean data on crop production by country, harvested area by country and crop yield in 2000 and projections for 2050 for Sub-Saharan Africa. (a) Present-day (year 2000) and (b) projected (year 2050) soybean production, harvested area, and yield for Africa. Presentday production and harvested area data are from FAO data (FAOSTAT), and the yield data in $0.1 \times 0.1$ resolution were obtained using a data fusion technique (Monfreda et al., 2008) scaled to be consistent with country-by-country FAO yield data (FAOSTAT). Year 2050 projections were derived by FAO (Alexandratos \& Bruinsma, 2012) and are driven by population and socio-economic trends constrained by land availability, yield growth potential and ceiling, and water availability and irrigation potential under present-day prevailing climatic conditions. Column (c) shows the growth factors, which are the values in column (b), divided by those in column (a). Blank colour denotes a lack of data or projections for soybean. Note that the direct biophysical effects of climate change are unaccounted for in these projections (Detailed data are shown in Table S3) [Colour figure can be viewed at wileyonlinelibrary.com]

emphasis with regard to different research questions, crops, and regions (Ewert et al., 2015). Observed and projected climate data are key inputs for these models. Land suitability models compare the crop requirements against local climatic conditions/characteristics (e.g., temperature, precipitation, and solar radiation), soil (texture, hydraulic properties, $\mathrm{pH}$, organic carbon content, salinity, acidity, or alkalinity), and topography (elevation and slope) scoring the area with a value between zero and unity. A value 1.0 is given if the area is perfectly suitable for producing the crop (Zabel, Putzenlechner, \& Mauser, 2014). When projected climate data are fed into such models, they are capable of predicting the possible changes in harvest area (Fodor et al., 2017). Crop models are designed to calculate crop yield (and other important parameters of the plant-soil system) as a function of weather and soil conditions, or plant-specific characteristics, as well as the choice of agricultural management practices. Statistical crop models usually express the relationship between yield or yield components and weather parameters in a form of regression equations (e.g., Lobell \& Burke, 2010), which are calibrated by using corresponding observed yield and weather data varying in time or space or in both domains. Process-based crop models simulate the key processes of the soil-plant system, including crop development (phenology), biomass accumulation, yield, water, and nutrient uptake, while taking into account the effects of environmental stresses as well as plant responses to elevated atmospheric carbon dioxide concentrations (e.g., Müller et al., 2017). Fodor et al. (2017) reported that the vast majority of soybean-related climate change impact studies using land suitability and/or crop models project positive changes for Sub-Saharan Africa.

\section{5 | MATERIALS AND METHODS}

The aim of the present study was to specifically evaluate the potential impacts of climate change on soybean production in Africa. We applied the methodology of Tai, Val, and Heald (2014) and Tai and Val (2017) that combined process-based modelling for climate and statistical modelling for crop-climate relationships and compared simulated results with an array of other modelling studies. In the first analysis, we used annual (1961-2010) data from FAO to derive high-resolution $\left(1.9^{\circ} \times 2.5^{\circ}\right.$ latitude-longitude) time series of annual soybean yield $(Y)$ using a data fusion technique (Monfreda et al., 2008) and extract meteorological data from the NCEP/NCAR 
Reanalysis 1 (Kalnay et al., 1996) to derive two important agroclimatic variables: growing degree day (GDD), which is the summation over the growing season of daily mean temperature above a minimum threshold $\left(10^{\circ} \mathrm{C}\right)$ but below a maximum optimum $\left(30^{\circ} \mathrm{C}\right)$ and represents the beneficial effect of warmth on yield; and killing degree day (KDD), which is the summation over the growing season of daily maximum temperature above the optimum $\left(30^{\circ} \mathrm{C}\right) . \mathrm{KDD}$ represents the adverse effect of temperature extreme and the associated heat and water stress. We applied a constrained linear regression model (Tai et al., 2014; Tai \& Val Martin 2017), to estimate the local sensitivities of $Y$ to GDD and KDD (i.e., $\partial \ln Y / \partial G D D$ and $\partial \ln Y / \partial$ KDD) across Africa where data were available. We then obtained climate projections from the Community Earth System Model version 1.2 , which is a global climate model that computes climate variables by dynamically simulating atmospheric, oceanic, and terrestrial processes. Projections were for two future scenarios for year 2050 following two Intergovernmental Panel on Climate Change Representative Concentration Pathways (RCPs): RCP8.5, representing a business-as-usual, pessimistic outlook for the future; and RCP4.5, which assumes an intermediate pathway with aggressive mitigation measures to reduce greenhouse gas (GHG) emissions. We finally applied the statistical sensitivities $\partial \ln Y / \partial \mathrm{GDD}$ and $\partial \mathrm{InY} / \partial \mathrm{KDD}$ to the future changes in GDD and KDD as projected by Community Earth System Model to estimate the changes in soybean yield from year 2000 to 2050 (Figure 4). In contrast to Tai et al. (2014), the projections reported here are not corrected for ozone damage, due to the paucity of ozone data (that are required to derive crop-ozone relationships) that are available for Africa.

We also compared our statistical projections with those from other studies (Deryng, Conway, Ramankutty, Price, \& Warren, 2014; Lobell et al., 2008; Rosenzweig et al., 2014; Tai et al., 2014; Thomas \& Rosegrant, 2015), which considered a comprehensive array of different statistical and process-based crop models to account for not only rising temperatures in addition to other biophysical factors that covary with climate, such as higher ambient $\mathrm{CO}_{2}$ levels and soil nitrogen limitations. The comparison is presented in Figure 5 and discussed in the next section.

\section{6 | RESULTS}

\subsection{Climate change is unlikely to have negative impacts on future soybean production in Africa}

The uncertainties of climate change that increase the risks of extreme weather conditions, traditional cropping patterns, and disease pressures present not only potential constraints but also opportunities for the successful expansion of soybean production across Africa (Lopez, 2012; Siddique et al., 2012). The potential agronomic and economic gains from intensification of soybean production by smallholder farmers therefore hinge on the resilience of new soybean cultivars and their stabilities of yield in the face of biotic and abiotic challenges.

Holistic crop simulation models provide important tools for the assessment of system level impacts of climate change on soybean cultivation in Africa. The RCPs are the four GHG concentration trajectories (Intergovernmental Panel on Climate Change, 2013), which are plausible depending on how much GHG is emitted in the future. Such projections suggest only marginal yield losses (-2\%) for RCP8.5 with yield gains (11\% and 13\%) for RCP2.6 and RCP4.5, respectively (Bhattarai, Secchi, \& Schoof, 2017). In contrast, climate simulations indicate that a $10 \%$ decrease in rainfall and a $3^{\circ} \mathrm{C}$ increase in temperature will result in a median yield reduction of $9 \%$ and $35 \%$, respectively, for groundnut in Bulawayo, Zimbabwe (Cooper et al., 2009). If climate change mitigation policies can secure a future $\mathrm{CO}_{2}$ concentration pathway below RCP4.5, then any future potential climatic problems for soybean production in Africa and countries with similar climates will be resolved. Moreover, if appropriate measures are taken, the potential negative effect increased atmospheric $\mathrm{CO}_{2}$ may have on micronutrients (Myers et al., 2014) may also be avoided.

Africa is one of the few continents where substantial arable land is available for crop production; and with mechanization, the land area under cultivation could grow significantly. Globally, land that is suitable for soybean production has shown a northward shift in recent years (Lant, Stoebner, Schoof, \& Crabb, 2016). The projected yield and sowing area gains suggest a large expansion in global soybean production, even though such shifts in production areas will depend
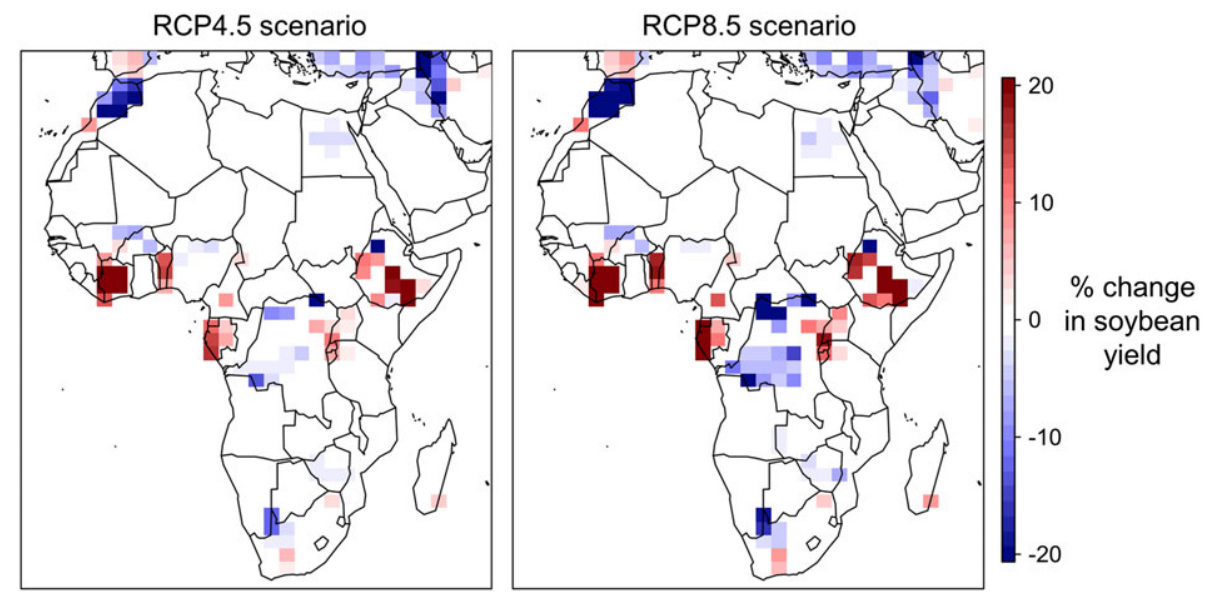

FIGURE 4 Projected impacts of 2000-2050 climate change on soybean yields for Sub-Saharan Africa. The projections are based on the statistical model of Tai et al. (2014) and Tai \& Val Martin (2017), driven by climate projections from a global climate model for two future scenarios following the Representative Concentration Pathways (RCP4.5 and RCP8.5) [Colour figure can be viewed at wileyonlinelibrary.com] 

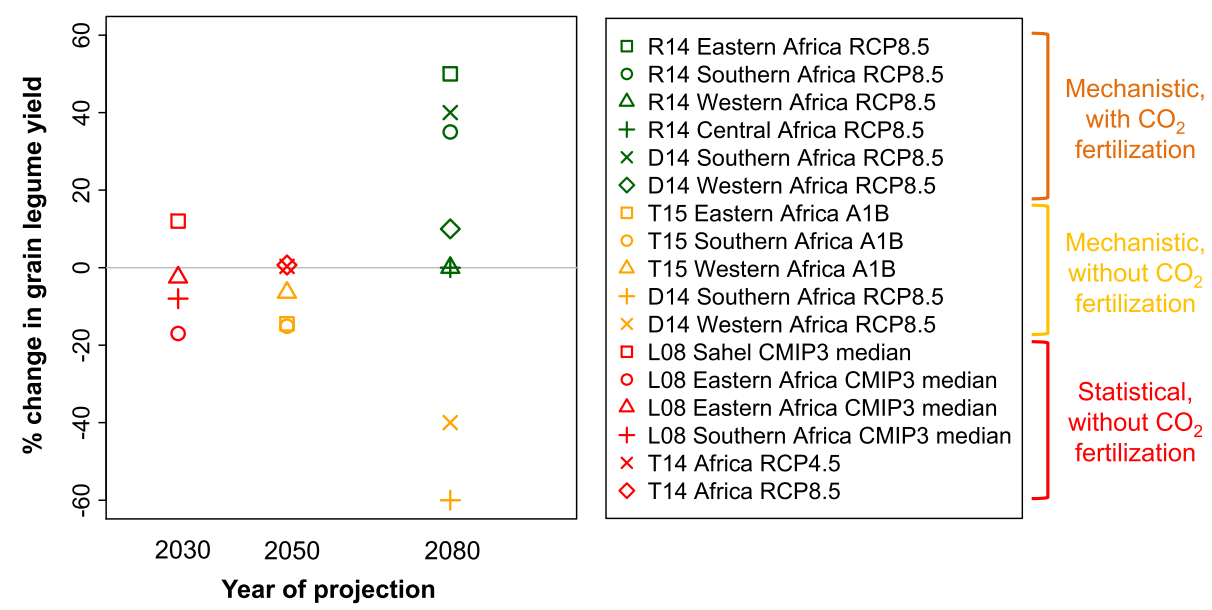

FIGURE 5 Climate change impacts on grain legume yield for Sub-Saharan Africa under various scenarios from different studies. Except for L08 Sahel (red rectangle = cowpea), L08 Eastern Africa (red circle = cowpea), and L08 Eastern Africa (red triangle = common bean), all other marks denote soybean yield changes. Values are either mean or median projections. Green and yellow marks denote projections from process-based (mechanistic) models with and without consideration of the $\mathrm{CO}_{2}$ fertilization effect, respectively; and red marks denote projections from empirical (statistical) models, none of which considers $\mathrm{CO}_{2}$ fertilization. The differences even for the same colors can be attributed to different climate scenarios, different model treatments of nitrogen fertilization and irrigation, and geographical variations in baseline production, climate, and soil quality. R14 stands for Rosenzweig et al. (2014), D14 stands for Deryng et al. (2014), T15 stands for Thomas and Rosegrant (2015), L08 stands for Lobell et al. (2008), and T14 stands for Tai et al. (2014), which presented statistical projections consistent with this study [Colour figure can be viewed at wileyonlinelibrary.com]

largely upon GHG emissions and the success of mitigation strategies (Tai et al., 2014; Tai \& Martin 2017). Major changes in policy, agricultural practice, and diet indicate that there will be major changes in the land areas dedicated to soybean production (Fodor et al., 2017). Although effective adaptation actions are required to mitigate the harmful impacts of climate change across Europe and other continents, Africa is at the other end of the spectrum. Climate change has the potential to allow a significant increase in soybean production in Africa, irrespective of which production scenario becomes reality in the future (Fodor et al., 2017). This finding should come as no surprise because soybean has already been called Africa's Cinderella crop (Kolapo, 2011). Moreover, a meta-analysis of projected changes in the production areas depicts a promising future for soybean (Lant et al., 2016). Based on this knowledge, we undertook a systematic modelling analysis of future trends based on all the available data for soybean and other major legume crops in Africa. The analysis of all-source data showed similar trends to those predicted by available FAO data. For simplicity and accessibility, we have therefore presented the predictions based only on the FAO data.

The projected changes in soybean yield in Africa in response to 2000-2050 climate change predictions from the statistical model used in the present analysis are shown in Figure 4. Across the two scenarios (RCP4.5 and RCP8.5), the impacts of 2000-2050 climate change alone on soybean yield in Africa are mostly within $\pm 10 \%$ in the major producer regions. These relative changes may, when superimposed on the socio-economic projections (Figure 3 ), further enhance or partly offset the projected increases in soybean yield. This prediction based on the historical relationships between yield and agro-climatic variables (Figure 4) shows a good agreement with other statistical models (Figure 5), despite the limitations caused by a lack of extensive data. However, future crop-climate relationships may be subject to altered conditions of simultaneous increases in atmospheric $\mathrm{CO}_{2}$ levels and nitrogen limitations, unless nodule nitrogen fixation can improve to meet the increasing demand (Aranjuelo, Arrese-lgor, \& Molero, 2014; Gray et al., 2016; Jensen et al., 2012). Most process-based models that explicitly simulate carbon and nitrogen dynamics on crop growth would generally project a large increase in soybean yield with future elevated $\mathrm{CO}_{2}$ levels, which offsets any possible negative impacts of climate change (Figure 5).

\section{7 | DISCUSSION}

Overall, the expected effects of climate change on agricultural production across Africa depend on the size of the "yield gap" of the underlying production system (Anderson et al., 2016). Climate change is likely to have a larger negative effect on intensive farming systems where crops perform near their genetic potential. In such intensive cropping systems, the prevalence of abiotic and/or biotic stress conditions is substantial and accents the positive effects of adopting new and improved cultivars with sustainable yield traits that are able to compensate for any yield-reduction effects of climate change. Expanding the adoption and dissemination of high-yielding soybean cultivars that are adapted to the agro-climatic conditions across Africa, and that address existing crop yield constraints while meeting market demands, should be the focus of intensive research. Ongoing genetic improvements in plant physiology, sustainability of yields, and biotic and abiotic stress tolerance are therefore essential to increase the resilience of soybeans to changing environmental conditions (Bishop, Betzelberger, Long, \& Ainsworth, 2015).

Inadequate early season rainfall and day length requirements for flowering may limit expansion of existing soybean varieties in Africa. However, varieties with increased tolerance for early season water deficits provide opportunities to increase yield sustainability in marginal 
regions by $>10 \%$ (Maxwell, 1996). Genetic variation in flowering time, as for example, exists in the germplasm resources of the United States, offers opportunities to extend the latitude range. Moreover, a vast amount of precise information on soybean responses to high $\mathrm{CO}_{2}$ in the absence or presence of other stresses has been gained from Free Air Carbon Dioxide Enrichment studies in the United States. Compelling evidence shows that drought stress will constrain $\mathrm{CO}_{2}$ fertilization effects in forecast climate scenarios (Bishop et al., 2015). However once again, considerable genetic variation exists in drought tolerance, providing opportunities to sustain or improve yields under conditions of limited water availability (Valliyodan et al., 2016). Extensive germplasm stocks and genetic tools are now available for soybean, with climate resilience featuring highly (Li et al., 2017; Sinclair et al., 2014; Valliyodan et al., 2016). More recent developments, such as the passing of Uganda's National Biosafety Act, provide further pathways to exploit genetic variation (Bendana, 2017). Such technological advances and political decisions will drive further growth in the soybean revolution (Alexandratos \& Bruinsma, 2012; Vadez et al., 2012).

Recent advances in genome editing technologies offer the potential to accelerate the breeding of current legume crops for diverse African environments. Genome editing-based breeding is faster than conventional or transgenic breeding and is not limited by available natural variation (Alexandratos \& Bruinsma, 2012; Bendana, 2017; Jacobs, LaFayette, Schmitz, \& Parrott, 2015; Li et al., 2015; Li et al., 2017; Schaeffer \& Nakata, 2015; Scheben \& Edwards, 2017; Vadez et al., 2012; Valliyodan et al., 2016). Zinc-finger nuclease-based editing has been successfully applied in legumes (Curtin et al., 2011). The CRISPR/Cas9 system is tending to dominate current thinking regarding future genetic engineering approaches to crop improvement and benefits from relatively low costs and high specificity (Jacobs et al., 2015; Li et al., 2015; Schaeffer \& Nakata, 2015; Scheben \& Edwards, 2017). Finally, strains of rhizobia that fix $\mathrm{N}_{2}$ at high rates are not always competitive for colonization and nodulation (Remigi, Zhu, Young, \& Masson-Boivin, 2016). They can be out-competed for nodule occupation by resident strains that have poor rates of $\mathrm{N}_{2}$-fixation. It therefore will be crucial to isolate and characterize highly effective strains that are also competitive for nodulation (Munoz et al., 2016). For example, Sinorhizobium is widespread in Chinese soil but has low $\mathrm{N}$-fixing efficiency with U.S. soybeans, which are typically inoculated with more effective Bradyrhizobium strains (Thoenes, 2016). However, these bacteria can have equal $\mathrm{N}$-fixation ability when partnered with certain Chinese soybean varieties, and some soybean genotypes are able to differentially restrict nodulation by specific serogroups of Bradyrhizobium or Sinorhizobium strains. Identification of genes that either exclude or substantially reduce nodulation by ineffective indigenous strains will be invaluable in improving the efficiency of symbiotic nitrogen fixation in African soils (Andrews \& Andrews, 2017; Bourion et al., 2018).

\section{8 | THE ROLE OF SOYBEAN IN POVERTY ALLEVIATION}

Soybean production is primed to expand rapidly to meet the rising demand for protein to feed animals and supply the increased meat demand across Africa. Local production could meet this demand either alone or in harmony with the production of other legumes such as cowpea and peanut that also produce protein that could supply the demand for animal feed. Much of Africa currently lacks the capital and equipment to mechanize the planting, weed control, and harvesting of soybean. Such limitations could be adequately addressed through the mobilization of governmental programmes with nongovernmental organizations support. South Africa is spearheading the intensification of soybean production in Africa, built on government and industry advocacy in support of soybean-maize rotations.

A major economic driver of the intensive expansion of soybean production, however, is the increasing level of household incomes and middle-class consumer preferences for meat and dairy products. This growing demand for meat protein has led to rising imports of soybean meal mainly from Argentina that over time have accounted for up to $90 \%$ of domestic feed demand (Ncube et al. 2016). Although today roughly $90 \%$ of Africa's soybean production is based in South Africa, Nigeria, Zambia, Malawi, Benin, and Zimbabwe, countries across Africa have experienced relatively high economic growth and urbanization resulting in growing populations of middle-class consumers (Melo et al., 2015). The associated shifts in consumption preferences combined with the emergence of a biofuel sector in South Africa are poised to incentivize growth in soybean cropping areas and the adoption of soybean-maize rotations where possible (Thoenes, 2016). Nonetheless, local farmer perceptions of soybean, as well as guidance in home garden versus cash crop farming and the availability of mechanization, still need to be addressed in some regions to ensure more widespread adoption through relaying the benefits to local farmers (de Jager, Abizari, Douma, Giller, \& Brouwer, 2017). In addition, although crop yield increases through the soil fertilization benefits of incorporating soybean into rotations or intercrops may be substantial (Ojiem, Franke, Vanlauwe, de Ridder, \& Giller, 2014), this effect may not be seen until three to four seasons of intervention have passed (Naab, Mahama, Yahaya, \& Prasad, 2017).

Strong demand in domestic (e.g., South Africa and Nigeria) and international (e.g., China) markets have made soybean an increasingly attractive cash crop. However, much of Africa is still importdependent, which under current favourable world market prices puts immense pressures on the soybean-feed, animal protein, and processed foods prices. Soybean production and market policies pursued by leading producers and exporters (i.e., the United States, Argentina, Brazil, and the EU) weigh heavily on the growth opportunities of a domestic African soybean industry. Market price and sector-specific support policies incentivize increased production, thus lowering international soybean price. In addition, greater funding opportunities for research and breeding programmes and non-specific income support programmes give soybean producers in major producer countries a significant competitive advantage over their current and future African competitors (Thoenes, 2016).

The development of economically sustainable soybean supply chains, especially outside of South Africa, will be no small feat (Monfreda et al., 2008). Nevertheless, producing enough soybeanbased feed and food in the region can create significant value-added products that will potentially save billions in foreign currency spent 
on feed imports. In 2013, Africa's imports of soybean, -oil, and -cake equalled US\$ 5.55 billion (FAOSTAT, 2017). For soybeans to generate the economic returns necessary to allow small- and medium-scale producers to benefit economically, possibly from future exports of soybean to Europe or Japan (Ncube et al., 2016), large-scale investments ranging from infrastructure to processing and marketing and sound regulatory systems are needed, especially outside South Africa. Favourable governance and government policies are typically a scarce resource in Africa, and therefore, productivity research and advanced genetics alone are likely not sufficient to drive African soybean industry's growth moving forward.

Without market-oriented policy changes across Africa that focus on generating private investment in marketing and transportation infrastructure, the privatization of state-owned grain elevators, port facilities, and railroads and the elimination of damaging agricultural policies (e.g., export taxes and import restrictions) are needed to allow investment to take place for an African soybean industry to emerge. Last but not the least, the economic success of soybean across Africa relies heavily on establishing regional trade relationships between a large number of producers and regional hubs of food and feed processing that may only build around major consumer and livestock markets. Such alliances are still rare across Africa, where the aforementioned lack of market liberalization has hindered the development of regional agricultural trade and supply chains (Ncube et al., 2016). This may especially have a negative impact on South African soybean production, which is closest to becoming a new hub for soybean production and processing in the African continent.

Sustainable agriculture and food security are largely inseparable from key social science issues concerning inequalities, organization of knowledge systems, and scientific collaboration. Changes in food production systems must be driven or designed in collaboration with farmers, local agricultural policymakers, and organizations that distribute the crops in question (Tadele, 2017). In the case of African soybean production, the driver is essentially economic, based on the certain knowledge that soybean markets and futures are secure but also science-based because soybean is well suited to Africa and a vast amount of germplasm is available for breeding and selection of improved cultivars. For example, Brazil has appropriate maturity classes that could be used in the different African environments.

\section{9 | CONCLUSIONS AND PERSPECTIVES}

The accelerated incorporation of soybean as a major cash crop and animal-feed protein in African production systems will be costeffective and address the dual challenges of malnutrition and climate change resilience. Africa has the potential to be a world leader in the production of soybean as well as other key grain legumes. The genetic yield potential of soybean in Africa has, yet, hardly been considered or exploited. There is a pressing need to develop superior soybean cultivars for Africa. Realizing the full potential of soybean production in Sub-Saharan Africa will require a concerted global effort of researchers, farmers, policy makers, and traders. Nevertheless, it is clear that soybean production is set to increase in Africa. Only the future will tell whether this occurs at the expense of other legumes. Moreover, the extent of success in terms of income generation depends on major adjustments in the market, for example, in terms of trade barriers and tariffs for imports such as soybean cake. However, limited and inconsistent regional production and producer price data currently complicate the reliability of predictions of the profitability of soybean supply-chain development. Although countries such as Zambia, Zimbabwe, and South Africa have the capital and mechanization to capitalize on these opportunities, we are optimistic that advances in soybean improvement, food chains, and pipelines wil percolate outwards to encompass the small-scale producers in Central and West Africa.

Soybean production is expected to dominate in the future in Africa due to its cash crop value from oil extraction and as animal feed. Governmental and agro-industries can help provide the required economic opportunities through improved soybean-based supply chains involving consumers and producers. With intensive support from nongovernmental agencies and research organizations, the typical African farmer's production efficiency can also be improved to address the current situation of lower than average yields and higher than average production costs. This problem of the current "yield gap" attributable to the production inefficiency in farming is not insurmountable, particularly if basic and social scientists can come together to jointly better identify and eliminate current bottlenecks to the potential for production improvements, especially from an African smallholder farmer's perspective.

We do not underestimate the challenges faced by resource-poor soybean producers, who are inclined to adopt risk-minimizing technologies due to the inherent high variability of returns from new cropping varieties. The risks of adoption of new varieties will be minimized if intensive efforts are made to select improved soybean varieties, together with the best rhizobial strains, that are suited to African climates and soils. Equally, the characteristically low adoption of technologies by farmers in Sub-Saharan Africa can be influenced by the demonstration of successful soybean production across the continent.

Poverty, hunger, and malnutrition are chronic problems in Africa, where agriculture employs most of the workforce and accounts for much of the gross domestic product. Grain legumes already play a key role in the improvement of livelihoods of the rural poor and urban consumers in Africa. Although a wide variety of different grain legumes will continue to be grown in Africa over the coming decades, the trend for enhanced soybean production as an economically viable and environmentally sustainable option for income generation can no longer be ignored. Soybean is already one of the five major crops that ensure global food security. In addition to the high value of soybeans as a cash crop, the beans are rich in high-quality protein, as well as fibre, minerals, and metabolites that are ideal for human and animal health. These attributes alone are providing a significant driver for African producers to overcome challenges that might impede or limit soybean production in Africa. Such challenges should therefore be addressed by effective application of science, engineering and crop management, policy, and social interventions, together with the development of a high-value food chain from production to consumption. 


\section{ACKNOWLEDGEMENTS}

The authors thank the Worldwide University Network (WUN) for financial support. C. F. and N. F. thank BBSRC for financial support (BB/N004914/1). The work of C. F. and N. F. was undertaken within the auspices of Modelling European Agriculture with Climate Change for Food Security (MACSUR), a FACCE JPI knowledge hub. The work of HML was supported by Hong Kong RGC Area of Excellence Scheme (AoE/M-403/16), CUHK VC Discretionary Fund VCF2014004, and the Lo Kwee-Seong Biomedical Research Fund. APKT thanks the General Research Fund (Project ID: 14323116) from Research Grants Council of Hong Kong and the Vice-Chancellor Discretionary Fund (Project ID: VCF2015006) from CUHK given to Institute of Environment, Energy, and Sustainability. B. F. thanks the Hermon Slade Foundation and ARC (DP130103084 and DP130102266, respectively) for financial support. M. J. C. acknowledges an ARC project (DP150103211). We thank Miss Cherry Lee (The Chinese University of Hong Kong) for helping to polish the figures and tables. We thank FAO for providing unpublished projection data for making Figure 3 .

\section{ORCID}

Christine H. Foyer (D) http://orcid.org/0000-0001-5989-6989

Michael J. Considine (D) http://orcid.org/0000-0002-4468-6820

P.V. Vara Prasad (D) http://orcid.org/0000-0001-6632-3361

Rajeev K. Varshney (D) http://orcid.org/0000-0002-4562-9131

Henry T. Nguyen (D) http://orcid.org/0000-0002-7597-1800

Hon-Ming Lam (D) http://orcid.org/0000-0002-6673-8740

\section{REFERENCES}

Akibode, S., \& Maredia, M. (2012). Global and regional trends in production, trade and consumption of food legume crops. In Department of agricultural, food, and resource economics staff paper series \#2012-10 (p. 89). Michigan State University.

Alexandratos, N., \& Bruinsma, J. (2012). World agriculture towards 2030/2050: the 2012 revision. In ESA working paper no. 12-03. Rome: $\mathrm{FAO}$.

Pan-Africa Bean Research Alliance. (2017) www.pabra-Africa.org.

Anderson, W., Johansen, C., \& Siddique, K. H. M. (2016). Addressing the yield gap in rainfed crops: A review. Agronomy for Sustainable Development, 36, 18. https://doi.org/10.1007/s13593-015-0341-y

Andrews, M., \& Andrews, M. E. (2017). Specificity in legume-rhizobia symbioses. International Journal of Molecular Sciences, 18, 705. https://doi. org/10.3390/ijms18040705

Aranjuelo, I., Arrese-Igor, C., \& Molero, G. (2014). Nodule performance within a changing environmental context. Journal of Plant Physiology, 171, 1076-1090. https://doi.org/10.1016/j.jplph.2014.04.002

Bendana C. (2017) Uganda removes key hurdle to GM crops. In: Sciencemag. http://www.sciencemag.org/news/2017/10/ugandaremoves-key-hurdle-gm-crops

Bhattarai, M. D., Secchi, S., \& Schoof, J. (2017). Projecting corn and soybeans yields under climate change in a Corn Belt watershed. Agricultural Systems, 152, 90-99. https://doi.org/10.1016/j. agsy.2016.12.013

Bill \& Melinda Gates Foundation (2012) Legume market analysis: Macro data $\&$ trends. https://agriknowledge.org/files/3197xm08n.

Bishop, K. A., Betzelberger, A. M., Long, S. P., \& Ainsworth, E. A. (2015). Is there potential to adapt soybean (Glycine max Merr.) to future $\left[\mathrm{CO}_{2}\right]$ ? An analysis of the yield response of 18 genotypes in free-air $\mathrm{CO}_{2}$ enrichment. Plant, Cell \& Environment, 38, 1765-1774. https://doi. org/10.1111/pce.12443

Bourion, V., Heulin-Gotty, K., Aubert, V., Tisseyre, P., Chabert-Martinello, M., Pervent, M., ... Lepetit, M. (2018). Co-inoculation of a pea corecollection with diverse rhizobial strains shows competitiveness for nodulation and efficiency of nitrogen fixation are distinct traits in the interaction. Frontiers in Plant Science, 8, 2249. https://doi.org/ 10.3389/fpls.2017.02249

Bureau for Food and Agricultural Policy (2017) http://www.bfap.co.za/.

Buruchara, R., Chirwa, R., Sperling, L., Mukankusi, C., Rubyogo, J. C. Mutonhi, R., \& Abang, M. M. (2011). Development and delivery of bean varieties in Africa: The Pan-Africa bean research alliance (PABRA) model. African Crop Science Journal, 18, 227-245.

Challinor, A. J., Müller, C., Asseng, S., Deva, C., Nicklin, K. J., Wallach, D., ... Koehler, A.-K. (2018). Improving the use of crop models for risk assessment and climate change adaptation. Agricultural Systems, 59, 296-306

Chivenge, P., Mabhaudhi, T., Modi, A. T., \& Mafongoya, P. (2015). The potential role of neglected and underutilised crop species as future crops under water scarce conditions in Sub-Saharan Africa. International Journal of Environmental Research and Public Health, 12, 5685-5711. https://doi.org/10.3390/ijerph120605685

Cooper, P., Rao, K. P. C., Singh, P., Dimes, J., Traore, P. C. S., Rao, K., ... Twomlow, S. J. (2009). Farming with current and future climate risk: Advancing a 'Hypothesis of Hope' for rainfed agriculture in the semi-arid tropics. Journal of SAT Agricultural Research, 7, 1-19.

Cullis, C., \& Kunert, K. J. (2017). Unlocking the potential of orphan legumes. Journal of Experimental Botany, 68, 1895-1903. https://doi. org/10.1093/jxb/erw437

Curtin, S. J., Zhang, F., Sander, J. D., Haun, W. J., Starker, C., Baltes, N. J., ... Stupar, R. M. (2011). Targeted mutagenesis of duplicated genes in soybean with zinc-finger nucleases. Plant Physiology, 156, 466-473. https://doi.org/10.1104/pp.111.172981

de Jager, I., Abizari, A.-R., Douma, J. C., Giller, K. E., \& Brouwer, I. D. (2017). Grain legume cultivation and children's dietary diversity in smallholder farming households in rural Ghana and Kenya. Food Security, 9, 1053-1071. https://doi.org/10.1007/s12571-017-0720-0

Deryng, D., Conway, D., Ramankutty, N., Price, J., \& Warren, R. (2014). Global crop yield response to extreme heat stress under multiple climate change futures. Environmental Research Letters, 9, 034011. https://doi.org/10.1088/1748-9326/9/3/034011

Ewert, F., Rötter, R. P., Bindi, M., Webber, H., Trnka, M., Kersebaum, K. C., ... Asseng, S. (2015). Crop modelling for integrated assessment of risk to food production from climate change. Environmental Modelling \& Software, 72, 287-303. https://doi.org/10.1016/j.envsoft.2014.12.003

FAO (2012). Smallholders and family formers. In: Sustainability Pathways. http://www.fao.org/nr/sustainability/fact-sheets/en/

FAOSTAT (2017) (Accessed 20.11.2017) http://www.fao.org/faostat.

Ferguson, B. J., Indrasumunar, A., Hayashi, S., Lin, M. H., Lin, Y. H., Reid, D. E., \& Gresshoff, P. M. (2010). Molecular analysis of legume nodule development and autoregulation. Journal of Integrative Plant Biology, 52, 61-76. https://doi.org/10.1111/j.1744-7909.2010.00899.x

Fodor, N., Challinor, A., Droutsas, I., Ramirez-Villegas, J., Zabel, F., Koehler, A. K., \& Foyer, C. H. (2017). Integrating plant science and crop modeling: Assessment of the impact of climate change on soybean and maize production. Plant and Cell Physiology, 58, 1833-1847. https://doi.org/ $10.1093 / \mathrm{pcp} / \mathrm{pc} \times 141$

Foyer, C. H., Lam, H. M., Nguyen, H. T., Siddique, K. H. M., Varshney, R. K., Colmer, T. D., ... Considine, M. J. (2016). Neglecting legumes has compromised human health and sustainable food production. Nature Plants, 2, 16112. https://doi.org/10.1038/nplants.2016.112

Gray, S. B., Dermody, O., Klein, S. P., Locke, A. M., McGrath, J. M., Paul, R. E., ... Leakey, A. D. B. (2016). Intensifying drought eliminates the expected benefits of elevated carbon dioxide for soybean. Nature Plants, 2, 16132. https://doi.org/10.1038/nplants.2016.132 
Gresshoff, P. M., Hayashi, S., Biswas, B., Mirzaei, S., Indrasumunar, A., Reid, D., ... Ferguson, B. J. (2015). The value of biodiversity in legume symbiotic nitrogen fixation and nodulation for biofuel and food production. Journal of Plant Physiology, 172, 128-136. https://doi.org/10.1016/j. jplph.2014.05.013

IPCC (2013). Summary for Policymakers. In T. F. Stocker, D. Qin, G.-K. Plattner, et al. (Eds.), Climate change 2013: The physical science basis. Contribution of Working Group I to the Fifth Assessment Report of the Intergovernmental Panel on Climate Change (pp. 1-30). Cambridge, United Kingdom: Cambridge University Press.

Jacobs, T. B., LaFayette, P. R., Schmitz, R. J., \& Parrott, W. A. (2015). Targeted genome modifications in soybean with CRISPR/Cas9. BMC Biotechnology, 15, 16. https://doi.org/10.1186/s12896-015-0131-2

Jensen, E. S., Peoples, M. B., Boddey, R. M., Gresshoff, P. M., HauggaardNielsen, H., Alves, B. J. R., \& Morrison, M. J. (2012). Legumes for mitigation of climate change and the provision of feedstock for biofuels and biorefineries. A Review. Agronomy for Sustainable Development 32, 329-364. https://doi.org/10.1007/s13593-011-0056-7

Jones, J. W., Antle, J. M., Basso, B., Boote, K. J., Conant, R. T., Foster, I., .. Wheeler, T. R. (2017). Brief history of agricultural systems modeling. Agricultural Systems, 155, 240-254. https://doi.org/10.1016/j. agsy.2016.05.014

Kalnay, E., Kanamitsu, M., Kistler, R., Collins, W., Deaven, D., Gandin, L., ... Joseph, D. (1996). The NCEP/NCAR 40-year reanalysis project. Bulletin of the American Meteorological Society, 77, 437-471. https://doi.org/ 10.1175/1520-0477(1996)077<0437:TNYRP>2.0.CO;2

Kerr, R. B., Snapp, S., Chirwa, M., Shumba, L., \& Msachi, R. (2007). Participatory research on legume diversification with Malawian smallholder farms for improved nutrition and soil fertility. Experimental Agriculture, 43, 437-453.

Keyser, J. C. (2007). Zambia competitiveness report. In Competitive Commercial Agriculture in Africa (CCAA). The World Bank.

Kolapo, A. L. (2011). Soybean: Africa's potential Cinderella food crop. In T. B. Ng (Ed.), Soybean. IntechOpen. https://doi.org/10.5772/15527

Lant, C., Stoebner, T. J., Schoof, J. T., \& Crabb, B. (2016). The effect of climate change on rural land cover patterns in the Central United States. Climatic Change, 138, 585-602. https://doi.org/10.1007/s10584-0161738-6

Li, M. W., Xin, D. W., Gao, Y. S., Li, K. P., Fan, K. J., Munoz, N. B., ... Lam, H. M. (2017). Using genomic information to improve soybean adaptability to climate change. Journal of Experimental Botany, 68, 1823-1834. https://doi.org/10.1093/jxb/erw348

Li, Z. S., Liu, Z. B., Xing, A. Q., Moon, B. P., Koellhoffer, J. P., Huang, L. X., ... Cigan, A. M. (2015). Cas9-Guide RNA directed genome editing in soybean. Plant Physiology, 169, 960-970. https://doi.org/10.1104/ pp.15.00783

Lobell, D. B., \& Burke, M. B. (2010). On the use of statistical models to predict crop yield responses to climate change. Agri. Forest Meteorol., 150 1443-1452. https://doi.org/10.1016/j.agrformet.2010.07.008

Lobell, D. B., Burke, M. B., Tebaldi, C., Mastrandrea, M. D., Falcon, W. P., \& Naylor, R. L. (2008). Prioritizing climate change adaptation needs for food security in 2030. Science, 319, 607-610. https://doi.org/ 10.1126/science.1152339

Lopez, K. (Ed.) (2012). A success tale on improving two legume crops in Africalnternational Institute of Tropical Agriculture. http://r4dreview. iita.org/index.php/tag/soybean/

Mauser, W., Klepper, G., Zabel, F., Delzeit, R., Hank, T., Putzenlechner, B., \& Calzadilla, A. (2015). Global biomass production potentials exceed expected future demand without the need for cropland expansion. Nature Communications, 6, 8946. https://doi.org/ 10.1038/ncomms9946

Maxwell, S. (1996). Food security: A post-modern perspective. Food Policy, 21, 155-170. https://doi.org/10.1016/0306-9192(95)00074-7

Melo P. C., Abdul-Salam Y., Roberts D., Gibert A., Matthews R., Colen L., Mary S. \& Paloma S. G. Y. (2015) Income elasticities of food demand in Africa: A meta-analysis. https://ec.europa.eu/jrc/en/publication/ income-elasticities-food-demand-africa-meta-analysis

Monfreda, C., Ramankutty, N., \& Foley, J. A. (2008). Farming the planet: 2. Geographic distribution of crop areas, yields, physiological types, and net primary production in the year 2000. Global Biogeochemical Cycles, 22, GB1022.

Müller, C., Elliott, J., Chryssanthacopoulos, J., Arneth, A., Balkovic, J., Ciais, P., ... Deryng, D. (2017). Global gridded crop model evaluation: benchmarking, skills, deficiencies and implications. Geoscientific Model Development, 10, 1403-1422.

Mueller, N. D., Gerbe, J. S., Johnston, M., Ray, D. K., Ramankutty, N., Foley, J. A. (2012). Closing yield gaps through nutrient and water management. Nature, 490, 254-257.

Munoz, N., Qi, X., Li, M. W., Xie, M., Gao, Y., Cheung, M. Y., ... Lam, H. M. (2016). Improvement in nitrogen fixation capacity could be part of the domestication process in soybean. Heredity, 117, 84-93. https://doi. org/10.1038/hdy.2016.27

Myers, S. S., Zanobetti, A., Kloog, I., Huybers, P., Leakey, A. D. B., Bloom, A J., ... Usui, Y. (2014). Increasing $\mathrm{CO}_{2}$ threatens human nutrition. Nature, 510, 139-142. https://doi.org/10.1038/nature13179

Naab, J. B., Mahama, G. Y., Yahaya, I., \& Prasad, P. V. V. (2017). Conservation agriculture improves soil quality, crop yield, and incomes of smallholder farmers in North Western Ghana. Frontiers in Plant Science, 8, 996. https://doi.org/10.3389/fpls.2017.00996

Ncube, P. S., Roberts, S., \& Zengeni, T. (2016). Development of the animal feed to poultry value chain across Botswana, South Africa, and Zimbabwe. In WIDER Working Paper. World Institute for Development Economic Research Helsinki: UNU-WIDER.

Ojiem, J. O., Franke, A. C., Vanlauwe, B., de Ridder, N., \& Giller, K. E. (2014). Benefits of legume-maize rotations: Assessing the impact of diversity on the productivity of smallholders in Western Kenya. Field Crops Research, 168, 75-85. https://doi.org/10.1016/j.fcr.2014.08.004

Ortega, D. L., Waldman, K. B., Richardson, R. B., Clay, D. C., \& Snapp, S. (2016). Sustainable intensification and farmer preferences for crop system attributes: Evidence from Malawi's Central and Southern regions. World Development, 87, 139-151. https://doi.org/10.1016/j. worlddev.2016.06.007

Porwollik, V., Muller, C., Elliott, J., Chryssanthacopoulos, J., lizumi, T., Raye, D. K., ... Wu, X. C. (2017). Spatial and temporal uncertainty of crop yield aggregations. European Journal of Agronomy, 88, 10-21. https:// doi.org/10.1016/j.eja.2016.08.006

Ray, D. K., Mueller, N. D., West, P. C., \& Foley, J. A. (2013). Yield trends are insufficient to double global crop production by 2050. PLoS One, 8 e66428. https://doi.org/10.1371/journal.pone.0066428

Remigi, P., Zhu, J., Young, J. P. W., \& Masson-Boivin, C. (2016). Symbiosis within symbiosis: Evolving nitrogen-fixing legume symbionts. Trends in Microbiology, 24, 63-75. https://doi.org/10.1016/j.tim.2015.10.007

Rosenzweig, C., Elliott, J., Deryng, D., Ruane, A. C., Muller, C., Arneth, A., .. Jones, J. W. (2014). Assessing agricultural risks of climate change in the 21st century in a global gridded crop model intercomparison. Proceedings of the National Academy of Sciences of the United States of America, 111, 3268-3273. https://doi.org/10.1073/pnas.1222463110

Schaeffer, S. M., \& Nakata, P. A. (2015). CRISPR/Cas9-mediated genome editing and gene replacement in plants: Transitioning from lab to field. Plant Science, 240, 130-142. https://doi.org/10.1016/j. plantsci.2015.09.011

Scheben, A., \& Edwards, D. (2017). Genome editors take on crops. Science, 355, 1122-1123. https://doi.org/10.1126/science.aal4680

Siddique, K. H. M., Johansen, C., Turner, N. C., Jeuffroy, M. H., Hashem, A., Sakar, D., ... Alghamdi, S. S. (2012). Innovations in agronomy for food legumes. A review. Agronomy for Sustainable Development, 32, 45-64. https://doi.org/10.1007/s13593-011-0021-5

Sinclair, T. R., Marrou, H., Soltani, A., Vadez, V., \& Chandolu, K. C. (2014). Soybean production potential in Africa. Global Food SecurityAgriculture Policy Economics and Environment, 3, 31-40. https://doi. org/10.1016/j.gfs.2013.12.001 
Tadele, Z. (2017). Raising crop productivity in Africa through intensification. Agronomy, 7, 22. https://doi.org/10.3390/agronomy7010022

Tai, A. P. K., \& Val Martin, M. (2017). Impacts of ozone air pollution and temperature extremes on crop yields: Spatial variability, adaptation and implications for future food security. Atmospheric Environment, 169, 11-21. https://doi.org/10.1016/j.atmosenv.2017.09.002

Tai, A. P. K., Val Martin, M., \& Heald, C. L. (2014). Threat to future global food security from climate change and ozone air pollution. Nature Climate Change, 4, 817-821. https://doi.org/10.1038/nclimate2317

Thoenes, P. (2016). Soybean-International commodity profile. In Background paper for the Competitive Commercial Agriculture in SubSaharan Africa (CCAA) Study. Food and Agriculture Organization of the United Nations.

Thomas, T. S., \& Rosegrant, M. W. (2015). Climate change impact on key crops in Africa: Using crop models and general equilibrium models to bound the predictions. In E. Aziz (Ed.), Climate change impact on key crops in Africa: Using crop models and general equilibrium models to bound the predictions (pp. 146-175). Rome, Italy: Food and Agricultural Organization of the United Nations (FAO).

Tilman, D., Balzer, C., Hill, J., \& Befort, B. L. (2011). Global food demand and the sustainable intensification of agriculture. Proceedings of the National Academy of Sciences of the United States of America, 108, 20260-20264. https://doi.org/10.1073/pnas.1116437108

Tilman, D., \& Clark, M. (2014). Global diets link environmental sustainability and human health. Nature, 515, 518-522. https://doi.org/10.1038/ nature13959

Timmer, C. P. (1997). Farmers and markets: The political economy of new paradigms. American Journal of Agricultural Economics, 79, 621-627. https://doi.org/10.2307/1244161

Timmer, C. P. (2004). Food security and economic growth: An Asian perspective. In W. Heinz (Ed.), Arndt Memorial Lecture. Canberra, Australia.

UNICEF-WHO-The World Bank Group (2017) Joint Child Malnutrition Estimates-2017 edition (Accessed 26.10.2017) https://data.unicef. org/resources/joint-child-malnutrition-estimates-2017-edition/.
Vadez, V., Berger, J. D., Warkentin, T., Asseng, S., Ratnakumar, P., Rao, K. P. C., ... Zaman, M. A. (2012). Adaptation of grain legumes to climate change: A review. Agronomy for Sustainable Development, 32, 31-44. https://doi.org/10.1007/s13593-011-0020-6

Valliyodan, B., Qiu, D., Patil, G., Zeng, P., Huang, J. Y., Dai, L., ... Nguyen, H. T. (2016). Landscape of genomic diversity and trait discovery in soybean. Scientific Reports, 6, 23598. https://doi.org/10.1038/srep23598

Wilson, R. T. (2015). The soybean value chain in Tanzania: A report from the Southern Highlands Food Systems Programme. In Sustainable food value chains knowledge platform. Food and Agriculture Organization of the United Nations (FAO). http://www.fao.org/sustainable-foodvalue-chains/library/details/en/c/285412/

Zabel, F., Putzenlechner, B., \& Mauser, W. (2014) Global agricultural land resources-A high resolution suitability evaluation and its perspectives until

\section{SUPPORTING INFORMATION}

Additional supporting information may be found online in the Supporting Information section at the end of the article.

Table S1. Wasting and stunting prevalence in children under age 5 in Sub-Saharan regions.

Table S2. Market price of the five top legumes in countries of SubSaharan Africa.

Table S3: FAO data of area harvested and production of five major legumes in Sub-Saharan regions (2005-2014).

How to cite this article: Foyer $\mathrm{CH}$, Siddique KHM, Tai APK, et al. Modelling predicts that soybean is poised to dominate crop production across Africa. Plant Cell Environ. 2018;1-13. https://doi.org/10.1111/pce.13466 